\title{
Note of the Executive Editor
}

DOI: $10.1134 / \mathrm{S} 003103010911001 \mathrm{X}$

This is a collection of papers on paleontological topics presented at the International Conference "Development of Early Paleozoic Biodiversity: Role of Biotic and Abiotic Factors and Event Correlation" (Moscow, Russia, June 26-28, 2008). The conference was organized by A.A. Borissiak Paleontological Institute, Russian Academy of Sciences, as a contribution to the International Geoscience Programme (IGCP) 503, "Ordovician Palaeogeography and Palaeoclimate" and Basic Research Programs 18 and 11 "Origin and Evolution of the Biosphere" and "Biodiversity and Gene Pool Dynamics," Russian Academy of Sciences.

The 12 articles of the collection combine several contemporary issues in paleontology of the Early Paleozoic. The first aspect is related to the reconstruction of the trophic structure of marine communities. There are three articles focused on this issue. The article by S.V. Rozhnov seeks to reconstruct and compare the trophic structures of the Vendian, Cambrian, and Ordovician marine communities. G.A. Afanasjeva considers the effect of the evolution of the filter system on the succession of the Paleozoic brachiopod communities. R.V. Gorjunova has shown the relationship between the evolution of the colonial growth habit of Ordovician moss animals of the class Stenolaemata and feeding adaptation. Several articles deal with some details of the morphology of important Paleozoic groups of invertebrates that are important both for taxonomic classification and for reconstruction of biotic relationships. R. Parsley' paper presents some unique data on the morphology and ontogeny of gogiids, the most widespread family of the Lower and Middle Cambrian eocrinoids (echinoderms); it is based on the extremely well-preserved material from Guizhou,
China. A.N. Solovjev provides an overview of the morphology, distribution, and different viewpoints on the systematic position of bothriocidaroid echinoids, the most ancient sea urchins. Modern and fossil animals often display micromorphic features; in his paper A.V. Pakhnevich describes the causes of this phenomenon in the modern and fossil brachiopods. A.A. Madison studies the shell structure of the first-formed shell of the Middle Ordovician orthid-like brachiopods from the Leningrad Region, Russia. Three papers deal with the paleobiogeography of various animal groups of the Ordovician. In her paper Ya. Ariunchimeg discusses the biogeographic and biostratigraphic significance of the Ordovician moss animals of Mongolia. In their paper Rozhnov and coauthors deal with the first records of Rhombifera echinoderms from Mongolia and discuss their biogeographic significance. O.B. Bondarenko and L.M. Ulitina compare the Ordovician corals of the Siberian and Mongolian basins. Based on their study of the Late Ordovician conodonts of the cherty rocks of central Kazakhstan, T.Yu. Tolmacheva and her collaborators reach some major biogeographic and biostratigraphic conclusions. In his extensive article A.V. Dronov compares eustatic and biotic events in the Ordovician paleobasins of the Russian and Siberian platforms.

Therefore, the publication of this collection of papers makes widely varied contributions to the study of paleogeography, trophic structure of the Early Paleozoic biota, and the relationships between the development of biota and climate and eustatic sea-level changes.

S. V. Rozhnov 